\title{
Microsatellite marker-based variation in the growth hormone genes of Nile tilapia (Oreochromis niloticus)
}

\author{
MST. SADIA ZAFRIN AND MD. SAMSUL ALAM* \\ Department of Fisheries Biology and Genetics \\ Bangladesh Agricultural University, Mymensingh 2202, Bangladesh \\ *Email: samsul.alam@bau.edu.bd
}

\begin{abstract}
Polymorphisms in growth hormone genes have been found to cause variation in growth performance of fish. The objective of the study was to reveal variations in microsatellite loci located in the growth hormone genes of Nile tilapia (Oreochromis niloticus). Five microsatellite loci namely GH-MS01, IGFII, IGFII-MS01, IGFII-MS03, and STR were analyzed to assess the genetic variation in the growth hormone genes of four stocks of $O$. niloticus viz. FBG-Mini Hatchery, FM-Mini hatchery, Eon Aquaculture Ltd. and BFRI. The microsatellite markers were amplified by polymerase chain reaction, separated by polyacrylamide gel electrophoresis and visualized through ethidium bromide staining. All the five loci were found to be polymorphic. The average number of alleles of FM-Mini hatchery stock (3.8) was found to be highest and that of the FBG-Mini hatchery (2.8) and Eon Aquaculture stocks was found to be lowest. The average observed heterozygosity $\left(H_{o}\right)$ value of the FM-Mini hatchery stock was the highest $(0.140)$ and that of FBG-Mini hatchery stock was the lowest $(0.040)$. On the other hand, the average expected heterozygosity $\left(H_{e}\right)$ was highest in the BFRI stock $(0.660)$ and lowest in the FM-Mini hatchery and FBG-Mini hatchery stock (0.432). The fixation index $\left(1-\left(H_{o} / H_{e}\right)\right.$ values were positive in all the loci (except locus GH-MS01 in Eon Aquaculture stock), which means these stocks (O. niloticus) were deficient in heterozygosity. Deviation from Hardy-Weinberg expectation at STR locus in FBG-Mini hatchery and Eon Aquaculture stocks were not significant but in all other cases the deviations were found to be significant. The results provide evidence that genetic variation exists within the growth hormone genes in all four stocks of $O$. niloticus. The polymorphisms that have been detected in the present study can be used to study association with growth and thus selection of fast growing Nile tilapia in Bangladesh.
\end{abstract}

Key words: Polymorphisms, Microsatellite, Oreochromis niloticus, Heterozygosity

\section{Introduction}

Aquaculture is the fastest-growing food production sector in the world providing half of the global fish supply. It is estimated that by 2030 , aquaculture production will grow by $37 \%$ over the production in 2016 (FAO 2018a). The Nile tilapia, Oreochromis niloticus was the fourth most contributing aquaculture species in the world (FAO 2018a). Considering its importance worldwide the GIFT strain of $O$. niloticus was developed by the then ICLARM (International Centre for Living Aquatic Resources Management, now WorldFish) through several generations of conventional selective breeding (Eknath et al. 2007). The GIFT project played an important role in the expansion of Nile tilapia culture (now reported in 87 countries) by helping to avoid the negative impacts of inbreeding or poor genetic management (Gjedrem 2012). Production of Nile tilapia has quadrupled over the past decade because of its suitability for aquaculture, marketability and stable market prices (Prabhu et al. 2019). The GIFT strain was introduced in Bangladesh in 1994 to boost aquaculture and since then there has been tremendous progress in tilapia farming in the country (Hussain et al. 2017). In 2016, Bangladesh ranked $4^{\text {th }}$ in Nile tilapia production with 342,567 MT among the world's total production of 5,898,752 MT (FAO 2018b). 
Improvement of performance traits through traditional selection integrated with molecular tools is fast and more accurate and allows us to understand the genetic mechanism affecting performance traits (Haldar 2018). Molecular marker technology is required to sustain the aquaculture industry, promote quality and confirm traceability documentation. Among the molecular markers microsatellites have been commonly used for characterization of fish species, because they are highly reproducible, polymorphic, co-dominant and widely distributed throughout the genome (Liu and Cordes 2004). Though most microsatellite loci are associated with anonymous genomic segments (Liu and Cordes 2004), an increasing body of research has demonstrated that some microsatellites are located within promoter and transcribed regions of the genome and may be involved in regulating gene expression and function (Chistiakov et al. 2006). These functional microsatellites may cause distinct phenotypes or influence physiological functioning by directly or indirectly affecting the expression and function of a given gene (Kashi and King 2006) allowing characterization of the phenotypes that result from the expressional variation of a given gene.

Growth is a trait of moderate to high heritability (Gjedrem et al. 2012) that displays a complex development and physiology. It involves both the increase of muscle cell number (hyperplasia) and cell size (hypertrophy), and the balance between both processes depends on the developmental stage, but it is also influenced by the environment. Growth is regulated by the hypothalamic-pituitary axis hormones which also control feeding behavior (Kawauchi and Sower 2006. Despite its good response to traditional selection, the sole application of phenotypic and relatedness information to improve growth rate might determine the loss of relevant genetic variation affecting the medium- and long-term performance of breeding programs (Eynard et al. 2016). In this sense, identification of allelic variants of moderate to large effect could be useful in marker-assisted selection (MAS). For example, Sultana et al. (2020) identified sex-linked microsatellite DNA markers, ARO172, which facilitated reliable differentiation between male and female genotypes of $O$. niloticus.

Recently MAS became a very popular method of indirect selection for production of the genetically improved fish in aquaculture breeding programme. Polymorphisms in the growth related genes such as Growth hormone $(\mathrm{GH})$, Insulin like growth factors-I and II, Somatolactin (SL), Myostatin (MSTN-1) and Prolactin (PRL) are associated with the growth rate of fish and have been the target of many breeding programmes that significantly improve fish production. Advances in molecular assisted breeding have enhanced the efficiency with which breeders can select superior phenotypes with best gene combinations.

Growth hormone $(\mathrm{GH})$ is a single-chain polypeptide that is synthesized and secreted by the anterior pituitary gland. GHs have a wide range of physiological regulatory functions, as they can regulate the metabolism of three major substances (sugars, lipids and proteins), and their primary effect on animals is to significantly increase the growth rate, promote the growth of muscles and bones, and decrease the fat content, thereby affecting the growth and development ( Reinecke et al. 2005). GH gene polymorphism is often associated with growth or production performance (Hua et al. 2009, Cheng et al. 2016) in animals. GHs have significant growthpromoting effects in fish, as they can promote protein synthesis, decrease fat content and accelerate the longitudinal growth of bones (Chatakondi et al. 1995). In addition, they can also promote food conversion efficiency and sexual maturity (Tsai et al. 1994). Thus, the GH gene 
MICROSATELLITE MARKER-BASED VARIATION IN THE GENES OF NILE TILAPIA

has become an important target gene for the selective breeding of growth traits. GH gene polymorphism studies have been carried out in many fish species, which has resulted in the identification of molecular markers such as microsatellites and SNPs that are significantly associated with growth traits in fishes such as Oreochromis niloticus (Jaser et al. 2017) and Cyprinus carpio (Liu et al. 2017) which have been proposed as potential targets for markerassisted selection in fish (Wang et al. 2019). We have characterized five microsatellite DNA markers located in five different growth related genes in selected stocks of the Nile tilapia $O$. niloticus in order to select better performing fish by marker assisted selection.

\section{Materials and Methods}

Collection of fish sample and extraction of genomic DNA: A total of 43 Nile tilapia, $O$. niloticus individuals were collected from four different stocks such as FBG-Mini Hatchery and FM-Mini Hatchery of Bangladesh Agricultural University, Eon Aquaculture Ltd. Muktagacha, Mymensingh and Freshwater Station of the Bangladesh Fisheries Research Institute (BFRI). The fish were electronically tagged and fin samples were collected from caudal fin and preserved in microfuge tube containing $95 \%$ ethanol and stored at $-18^{\circ} \mathrm{C}$. The fish were stocked in cemented cistern at the FBG-Mini hatchery. Genomic DNA was extracted from fin tissues according to the method described by Alam and Islam (2005) with some modifications.

Amplification of microsatellite markers by PCR and electrophoretic separation: Five sets of microsatellite primers for growth hormone genes of $O$. niloticus such as GH- MS01, IGF- II, IGF- II- MS01, IGF-II- MS03, STR were analyzed (Table I). The polymerase chain reaction was conducted in a volume of $20 \mu \mathrm{l}$ containing $1 \mathrm{x}$ buffer with $\mathrm{MgCl}_{2}$, dNTPs, and $0.2 \mu \mathrm{M}$ dNTPs and 1 unit Taq DNA polymerase. The thermal profile consisted of 3 min initial denaturation at $95^{\circ} \mathrm{C}$, followed by 35 cycles each comprising of $30 \mathrm{~s}$ denaturation at $95^{\circ} \mathrm{C}, 45 \mathrm{~s}$ annealing at $60^{\circ} \mathrm{C}$ and 1.15 min elongation at $72^{\circ} \mathrm{C}$. The last cycle was followed by a single elongation step of $7 \mathrm{~min}$ at $72^{\circ} \mathrm{C}$. The PCR products were electrophoresed on polyacrylamide gel and stained with ethidium bromide. Photographs of the stained gels were taken using a gel documentation system and saved for further analysis.

Table I. Primer sequences and repeat motifs of five microsatellites located within growth-related genes

\begin{tabular}{|c|c|c|c|c|}
\hline $\begin{array}{l}\text { Primer } \\
\text { name }\end{array}$ & Primer sequence $\left(5^{\prime}-3^{\prime}\right)$ & $\begin{array}{l}\text { Position } \\
\text { within gene }\end{array}$ & Repeat & $\begin{array}{l}\text { Gene Bank } \\
\text { ID/ Reference }\end{array}$ \\
\hline \multirow{2}{*}{$\begin{array}{l}\text { GH- } \\
\text { MS01 }\end{array}$} & F: CCAGCCATGAACTCAGGTAAGACA & \multirow{2}{*}{$\begin{array}{l}\text { intron } 1 \text { of } \\
\text { GH }\end{array}$} & \multirow[t]{2}{*}{ TGTC } & \multirow[t]{2}{*}{ M97765 } \\
\hline & R: TGCTGAGAGGAGACGCCCAAACA & & & \\
\hline \multirow[t]{2}{*}{ IGF-II } & F: GGGAGCCGTGATGAAGACTG & \multirow{2}{*}{$\begin{array}{l}\text { Intron-3, } \\
\text { Exon-3 }\end{array}$} & \multirow[t]{2}{*}{ - } & \multirow{2}{*}{$\begin{array}{l}\text { Khatab et al. } \\
\text { (2014) }\end{array}$} \\
\hline & R: CAAATAGCAATCACG CAG C & & & \\
\hline \multirow{2}{*}{$\begin{array}{l}\text { IGF-II- } \\
\text { MS01 }\end{array}$} & F: TCCCCAGCTGGAAGATGTGTCACG & \multirow{2}{*}{$\begin{array}{l}\text { promoter of } \\
\text { IGF-II }\end{array}$} & \multirow[t]{2}{*}{ CT } & \multirow[t]{2}{*}{ AF033802 } \\
\hline & R: CTGGACGCAGCTGAAATCCTGTGG & & & \\
\hline \multirow{2}{*}{$\begin{array}{l}\text { IGF-II- } \\
\text { MS03 }\end{array}$} & F: ATGCTAGCAAACATCAAAGGTC & \multirow{2}{*}{$\begin{array}{l}\text { 3'UTR of } \\
\text { IGF-II }\end{array}$} & \multirow[t]{2}{*}{ ATCT } & \multirow[t]{2}{*}{ AF033804 } \\
\hline & R: GATATGCTGATGATGCACAGAGTC & & & \\
\hline \multirow[t]{2}{*}{ STR } & $\begin{array}{l}\text { F:TGTAAAACGACGGCCAGTCCAGCATG } \\
\text { TTTGCACTGAGTA }\end{array}$ & \multirow[t]{2}{*}{ Promoter } & \multirow[t]{2}{*}{ ATTCT } & \multirow[t]{2}{*}{ M97766 } \\
\hline & R: GCCTAGCCATGGACACATTTA & & & \\
\hline
\end{tabular}


Analysis of microsatellite marker data: The bands representing particular alleles at the microsatellite loci were scored by using AlphaEaseFC version 4.0 software from the gel image and the sizes of the bands/alleles were determined with respect to the 100bp DNA marker. A single genotype data matrix was constructed for all loci. The software GenAlEx version 6.503 (Peakall and Smouse 2012) was used to calculate the allelic variations, observed $\left(H_{o}\right)$ and expected $(\mathrm{He})$ heterozygosity, fixation index (inbreeding value), and test for Hardy-Weinberg Expectation.

\section{Results}

Allele frequency and size variation within stocks: The sizes and frequencies of alleles of the five microsatellite loci in four different stocks are shown in Table II. The sizes of the alleles for all loci in four stocks ranged from 142 to $488 \mathrm{bp}$. Four alleles were found at three loci (GH-MS01, IGFII-MS01 and STR) while five alleles were found at two loci (IGFII and IGFII-MS03) (Table II). Three (142 bp, $148 \mathrm{bp}, 158 \mathrm{bp}$ ) out of four allelic variants at locus GH-MS01 were absent in the samples of Eon Aquaculture while the other three stocks had lacked one single variant (148bp for BFRI, and 158bp forFBG-Mini hatchery and FM-Mini hatchery). Out of the four alleles in the locus IGFII, alleles 440bp and 457bp were absent in FBG-Mini hatchery stock

Table II. Allele Frequencies at five microsatellite loci in four stocks of $O$. niloticus

\begin{tabular}{l|c|c|c|c|c}
\hline Locus & $\begin{array}{c}\text { Allele } \\
(\mathrm{bp})\end{array}$ & $\begin{array}{c}\text { FBG-Mini } \\
\text { hatchery }\end{array}$ & $\begin{array}{c}\text { FM-Mini } \\
\text { hatchery }\end{array}$ & $\begin{array}{c}\text { Eon Aquaculture } \\
\text { Ltd. }\end{array}$ & BFRI \\
\hline GH-MS01 & 142 & 0.700 & 0.400 & 0.000 & 0.000 \\
\hline & 148 & 0.200 & 0.400 & 0.000 & 0.429 \\
\hline & 152 & 0.100 & 0.200 & 1.000 & 0.286 \\
\hline IGF-II & 158 & 0.000 & 0.000 & 0.000 & 0.286 \\
\hline & 440 & 0.000 & 0.050 & 0.667 & 0.429 \\
\hline & 457 & 0.000 & 0.050 & 0.333 & 0.429 \\
\hline & 471 & 0.700 & 0.300 & 0.000 & 0.143 \\
\hline IGFII-MS01 & 480 & 0.200 & 0.500 & 0.000 & 0.000 \\
\hline & 488 & 0.100 & 0.100 & 0.000 & 0.000 \\
\hline & 206 & 0.000 & 0.400 & 0.333 & 0.071 \\
\hline IGFII-MS03 & 212 & 0.900 & 0.500 & 0.333 & 0.500 \\
\hline & 220 & 0.100 & 0.100 & 0.333 & 0.357 \\
\hline & 233 & 0.000 & 0.000 & 0.000 & 0.071 \\
\hline & 194 & 0.200 & 0.500 & 0.111 & 0.286 \\
\hline & 210 & 0.100 & 0.400 & 0.500 & 0.107 \\
\hline STR & 232 & 0.600 & 0.000 & 0.222 & 0.321 \\
\hline & 243 & 0.100 & 0.050 & 0.167 & 0.107 \\
\hline & 177 & 0.000 & 0.050 & 0.000 & 0.179 \\
\hline & 185 & 0.000 & 0.500 & 0.056 & 0.000 \\
\hline & 194 & 0.600 & 0.200 & 0.611 & 0.357 \\
\hline & 204 & 0.400 & 0.100 & 0.056 & 0.286 \\
\hline & & 8 & 3 & 8 & 4 \\
\hline & & & & & \\
\hline & & & & & 0.278 \\
\hline
\end{tabular}


while allele $471 \mathrm{bp}$ and 488 were absent in Eon Aquaculture; the BFRI stock lacked only one allele (488bp) in this locus. In locus IGFII-MS01, the allele 206bp was absent in the FBG-Mini hatchery stock while the allele $233 \mathrm{bp}$ was absent in the rest three stocks. Allele 226bp of locus IGFII-MS03 was absent in FM-Mini hatchery stock and the allele 243bp was absent in the FBGMini hatchery and Eon Aquaculture stock. The $177 \mathrm{bp}$ and $185 \mathrm{bp}$ alleles of STR were absent in FBG-Mini hatchery and BFRI stocks. Overall a maximum 8 alleles were absent in each of FBGMini hatchery and Eon Aquaculture stocks. The numbers of missing alleles in the FM-Mini hatchery and BFRI were 3 and 4 respectively (Table II).

Genetic variation: Five microsatellite loci namely GH-MS01, IGFII, IGFII-MS01, IGFII-MS03, STR were analyzed in this study and except loci GH-MS01 all of them were found to be polymorphic (P95) in these four stocks. The GH-MS01 locus in Eon Aquaculture stock was found to be monomorphic. The microsatellite profiles of the IGFII-MS01 is shown in Fig. 1. The average number of alleles in FM-Mini hatchery stock (3.8) was found to be the highest and that of FBG-Mini hatchery and Eon Aquaculture stock (2.8) was found to be the lowest.
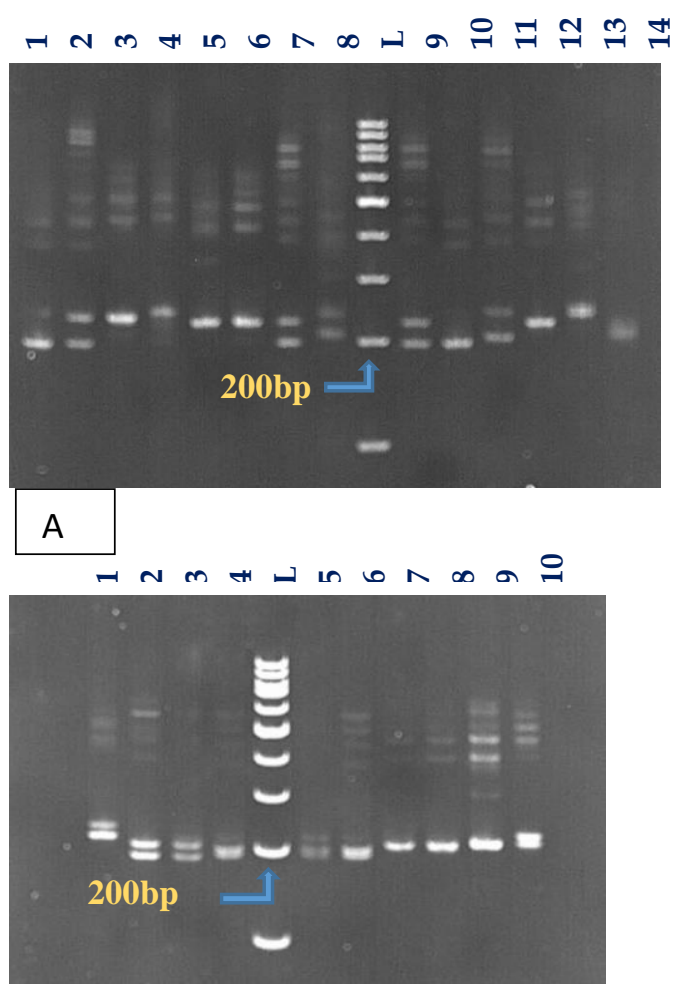

C
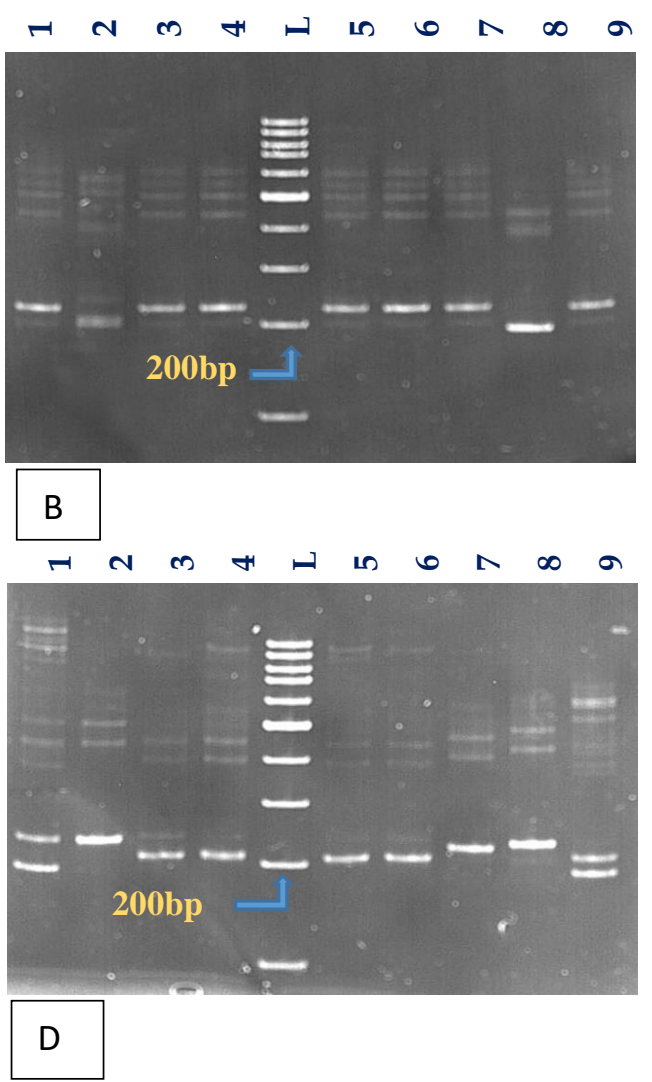

Fig. 1. Microsatellite profile of the locus IGFII-MS01 in BFRI (A), FBG-Mini hatchery (B), FM-Mini hatchery (C) and Eon Aquaculture Ltd. (D) stocks of $O$. niloticus. 
Deviation from Hardy-Weinberg expectation: Significant deviations from Hardy-Weinberg Expectation (HWE) were detected in 17 out of 20 tests (Table IV). The test for fit to HardyWeinberg expectations revealed that BFRI stock was highly deviated compared to other stocks. These deviations were not systematic rather occurred at different loci for different stocks. The deviation from HWE at loci GH-MS01, IGFII, IGFII-MS03 in FBG-Mini hatchery stock, GHMS01, IGFII-MS01, IGFII-MS03 in FM-Mini hatchery stock, IGFII-MS01 in the Eon Aquaculture stock and all five loci in the BFRI stock were high $(p<0.001)$. STR locus in FBGMini hatchery and Eon Aquaculture stocks was not deviated (Table IV).

Table III. Allelic variations at five microsatellite loci in four different stocks of $O$. niloticus $(\mathrm{N}=$ No. of individuals, $\mathrm{Na}=\mathrm{No}$. of alleles, $\mathrm{Ho}=$ Heterozygosity observed, $\mathrm{He}=$ Heterozygosity expected, $1-(\mathrm{Ho} / \mathrm{He})=$ Fixation index $)$

\begin{tabular}{|c|c|c|c|c|c|}
\hline $\begin{array}{l}\text { Microsatellite } \\
\text { loci }\end{array}$ & Parameters & $\begin{array}{l}\text { FBG-Mini } \\
\text { hatchery } \\
(\mathrm{N}=10)\end{array}$ & $\begin{array}{l}\text { FM-Mini } \\
\text { hatchery } \\
(\mathrm{N}=10)\end{array}$ & $\begin{array}{c}\text { Eon } \\
\text { Aquaculture } \\
\text { Ltd. }(\mathrm{N}=9)\end{array}$ & $\begin{array}{c}\text { BFRI } \\
(\mathrm{N}=14)\end{array}$ \\
\hline \multirow[t]{4}{*}{ GH-MS01 } & $N_{a}$ & 3.000 & 3.000 & 1.000 & 3.000 \\
\hline & $H_{o}$ & 0.000 & 0.000 & 0.000 & 0.000 \\
\hline & $H_{e}$ & 0.460 & 0.640 & 0.000 & 0.653 \\
\hline & $1-\left(H_{o} / H_{e}\right)$ & 1.000 & 1.000 & \#N/A & 1.000 \\
\hline \multirow{4}{*}{ IGFII } & $N_{a}$ & 3.000 & 5.000 & 2.000 & 3.000 \\
\hline & $H_{o}$ & 0.000 & 0.200 & 0.000 & 0.000 \\
\hline & $H_{e}$ & 0.460 & 0.645 & 0.444 & 0.612 \\
\hline & $1-\left(H_{o} / H_{e}\right)$ & 1.000 & 0.690 & 1.000 & 1.000 \\
\hline \multirow[t]{4}{*}{ IGFII-MS01 } & $N_{a}$ & 2.000 & 3.000 & 3.000 & 4.000 \\
\hline & $H_{o}$ & 0.000 & 0.000 & 0.000 & 0.000 \\
\hline & $H_{e}$ & 0.180 & 0.580 & 0.667 & 0.612 \\
\hline & $1-\left(H_{o} / H_{e}\right)$ & 1.000 & 1.000 & 1.000 & 1.000 \\
\hline \multirow[t]{4}{*}{ IGFII-MS03 } & $N_{a}$ & 4.000 & 4.000 & 4.000 & 5.000 \\
\hline & $H_{o}$ & 0.000 & 0.300 & 0.222 & 0.357 \\
\hline & $H_{e}$ & 0.580 & 0.585 & 0.660 & 0.760 \\
\hline & $1-\left(H_{o} / H_{e}\right)$ & 1.000 & 0.487 & 0.664 & 0.530 \\
\hline \multirow[t]{4}{*}{ STR } & $N_{a}$ & 2.000 & 4.000 & 4.000 & 3.000 \\
\hline & $H_{o}$ & 0.200 & 0.200 & 0.222 & 0.143 \\
\hline & $H_{e}$ & 0.480 & 0.660 & 0.543 & 0.663 \\
\hline & $1-\left(H_{o} / H_{e}\right)$ & 0.583 & 0.697 & 0.591 & 0.785 \\
\hline \multicolumn{2}{|c|}{ Average number of alleles } & 2.8 & 3.8 & 2.8 & 3.6 \\
\hline \multicolumn{2}{|c|}{ Average $\mathrm{H}_{\mathrm{o}}$ over loci } & 0.040 & 0.140 & 0.089 & 0.100 \\
\hline \multicolumn{2}{|c|}{ Average $\mathrm{He}_{\mathrm{e}}$ over loci } & 0.432 & 0.622 & 0.463 & 0.660 \\
\hline \multicolumn{2}{|c|}{ Polymorphism (P95) } & $100 \%$ & $100 \%$ & $80 \%$ & $100 \%$ \\
\hline
\end{tabular}

\section{Discussion}

In the present study, we have characterized five growth regulatory genes by microsatellite DNA markers and detected a total of 22 alleles in 43 individuals of four sources. The average number of alleles ranged from 2.8 to 3.8 in the four stocks. With one exception, locus GH-MS01 in Eon Aquaculture stock, all the loci were found to be polymorphic meaning there exist variations in all the loci in all the stock. As many as five alleles have been found at locus IGFII in FM-Mini 
MICROSATELLITE MARKER-BASED VARIATION IN THE GENES OF NILE TILAPIA

hatchery stock and at locus IGFII-MS03 in BFRI stocks. The allelic variations observed in the four stocks of $O$. niloticus suggest that there is scope for improvement in growth performance if the alleles are associated with growth performance. Detection of polymorphisms and characterization of growth traits in Nile tilapia using microsatellite DNA markers have also been reported by a few authors (Yue et al. 2002, Chi et al. 2014, Khatab et al. 2014, Dias et al. 2019). The previously identified microsatellite markers located in the growth hormone genes have been found to be effective in the present study to detect genetic variation in the Bangladesh stocks of $O$. niloticus.

Table IV. Deviation from Hardy-Weinberg genotype frequency expectations in four different stocks of $O$. niloticus ( $\chi 2$ values, followed by degrees of freedom in parenthesis)

\begin{tabular}{|c|c|c|c|c|c|}
\hline Pop & Locus & ChiSq & $\mathrm{DF}$ & Prob. & Signific. \\
\hline \multirow[t]{5}{*}{ FBG-Mini hatchery } & GH MS01 & 20.000 & 3 & 0.000 & $* * *$ \\
\hline & IGFII & 20.000 & 3 & 0.000 & $* * *$ \\
\hline & IGFII MS01 & 10.000 & 1 & 0.002 & $* *$ \\
\hline & IGFIIMS03 & 30.000 & 6 & 0.000 & *** \\
\hline & STR & 3.403 & 1 & 0.065 & NS \\
\hline \multirow[t]{5}{*}{ FM-Mini hatchery } & GH MS01 & 20.000 & 3 & 0.000 & $* * *$ \\
\hline & IGFII & 20.400 & 10 & 0.026 & $*$ \\
\hline & IGFII MS01 & 20.000 & 3 & 0.000 & $* * *$ \\
\hline & IGFIIMS03 & 23.025 & 6 & 0.001 & $* * *$ \\
\hline & STR & 20.000 & 6 & 0.003 & $* *$ \\
\hline \multirow{5}{*}{$\begin{array}{l}\text { Eon Aquaculture } \\
\text { limited }\end{array}$} & GH MS01 & \multicolumn{4}{|c|}{ Monomorphic } \\
\hline & IGFII & 9.000 & 1 & 0.003 & $* *$ \\
\hline & IGFII MS01 & 18.000 & 3 & 0.000 & $* * *$ \\
\hline & IGFIIMS03 & 15.111 & 6 & 0.019 & $*$ \\
\hline & STR & 9.434 & 6 & 0.151 & NS \\
\hline \multirow[t]{5}{*}{ BFRI } & GH MS01 & 28.000 & 3 & 0.000 & $* * *$ \\
\hline & IGFII & 28.000 & 3 & 0.000 & $* * *$ \\
\hline & IGFII MS01 & 42.000 & 6 & 0.000 & $* * *$ \\
\hline & IGFIIMS03 & 31.755 & 10 & 0.000 & $* * *$ \\
\hline & STR & 18.235 & 3 & 0.000 & $* * *$ \\
\hline
\end{tabular}

Key: NS $=$ not significant, $* p<0.05,{ }^{* *} p<0.01, * * * p<0.001$

We found the average expected heterozygosity values $(0.432,0.622,0.463,0.660)$ higher the average observed heterozygosity values $(0.040,0.140,0.089,0.100)$ in all the studied stocks. Yue and Orban (2002) reported that average expected heterozygosity was higher than average observed heterozygosity in Nile tilapia due to selective breeding. An et al. (2011) also found higher average expected heterozygosity values than average observed heterozygosities values in the hatchery stock. The fixation index $\left(1-\left(H_{o} / H_{e}\right)\right.$ values were mostly found to be positive in all the loci which means these stocks (O. niloticus) were deficient in heterozygosity indicating occurrence of inbreeding in the stocks. 
The test for fit to HWE revealed that BFRI stock is highly deviated than other stocks. The deviation from HWE at loci GH-MS01, IGFII, IGFII-MS03 in FBG-mini hatchery stock, at loci GH-MS01, IGFII-MS01, IGFII-MS03 in FM-mini hatchery stock, at loci IGFII-MS01 in Eon Aquaculture stock and at loci GH MS01, IGFII, IGFII MS01, IGFII-MS03, STR in the BFRI stock were highly significant $(p<0.001)$. Deviation from HWE in STR locus in FBG-mini hatchery stock and Eon Aquaculture stock were not significant $(p>0.05)$. There are many causes for disequilibrium such as inbreeding, selection, mutation, and migration. Samples used for this analysis were taken from hatcheries. In these hatcheries, the stocks of most Nile tilapia strains originated from a small number of parent stock and have been gradually enlarged. As a result, their genetic bases are narrow and founder effects could have had a great influence on these stocks. Secondly, many breeding schemes executed in these hatcheries might give rise to an increase in the inbreeding coefficient. Alam and Islam (2005) reported that all the studied stocks of Catla catla deviated from Hardy-Weinberg equilibrium at a number of loci, mostly due to deficiency in heterozygosity. Lal et al., (2004) detected significant heterogeneity in allele frequencies that indicated analyzed samples did not belong to homogenous stock.

Molecular marker-assisted selection increases the selection precision and reduces the number of generations required to achieve a desired improvement. Khatab et al. (2014) found nucleotide sequence variation in DNA sequencing of 397 bp fragment of IGF-II gene between large size and small size tilapia in Egypt. Juhua et al. (2010) demonstrated that two sites, G161A in exon 3 and the microsatellite locus in intron 3, were significantly associated with male growth of genetically improved farmed tilapia (GIFT). In fish, IGF-II is expressed in many tissues (Peng and Luo 2007) and molecular markers in IGF-IIare associated with back fat, fat deposition, body weight or other characteristics in chicken, goat and cattle (Li et al. 2004, Zhang et al. 2007, Helal et al. 2014). Therefore, our study revealed that the microsatellite markers in the growth related genes in $O$. niloticus can be used for marker assisted selection (MAS) for developing fast growing fish.

Dias et al. (2019) observed association of polymorphisms of short tandem repeats loci located in the growth hormone-I promoter and first intron with growth performance in introgressive crossbreed between Red-Stirling and Chitralada strains of the Nile tilapia. They found six alleles in the promoter, which were arranged in 18 of the 21 genotypic possible combinations. Jaser et al. (2017) in a study involving association between SNPs in growth hormones gene and growth rate of two strains of $O$. niloticus identified 10 SNPs, nine in the proximal promoter and one located in the $5^{\prime}$ UTR, forming 10 genotype blocks. They observed five genotype blocks which were significantly associated with the highest weights. These findings may be used as part of marker-assisted selection in tilapia breeding programmes.

Growth rate is an important trait for aquaculture species which is influenced by genotype and environmental factors (Schwartz et al. 2006). Polymorphisms present in a functional gene would create variation in the genotype and phenotype that can be exploited through selective breeding for stock improvement. Polymorphisms in the growth hormone gene that is associated with the growth rate of farmed fish have been the target of many breeding programmes. We have identified a total of 22 alleles in five growth related genes in $O$. niloticus. As the previous studies have detected significant association between the polymorphisms in SNPs and/or microsatellite loci in the growth hormones genes with growth performance, the alleles that we 
MICROSATELLITE MARKER-BASED VARIATION IN THE GENES OF NILE TILAPIA

have identified may be used to study association between growth performance and the alleles. This will allow to select faster growth rate fish by marker assisted selection.

Acknowledgements: The study was conducted with a Special Allocation fund for the year 2018-2019 of the Ministry of Science and Technology, Government of the People's Republic of Bangladesh (Grant No. BS57/68/2018-2019). We acknowledge BFRI and Eon Aqiaculture Ltd. For generously providing samples of O. niloticus.

\section{Literature Cited}

Alam, M.S. and M.S. Islam, 2005. Population genetic structure of Catla catla (Hamilton) revealed by microsatellite DNA markers. Aquaculture, 246: 151-160.

An, H.S.E. M. Kim, J.W. Lee, C.M. Dong, B.I. Lee and Y.C. Kim, 2011. Novel polymorphic microsatellite loci for the Korean black scraper (Thamnaconus modestus), and their application to the genetic characterization of wild and farmed populations. Int. J. Molec. Sci., 12(6): 4104-4119.

Chatakondi, N., R.T. Lovell, P.L. Duncan, M. Hayat, T.T. Chen and D.A. Powers, 1995. Body composition of transgenic common carp, Cyprinus carpio, containing rainbow trout growth hormone gene. Aquaculture, 138: 99-109.

Cheng, Y., S. Liu, D. Su, C. Lu, X. Zhang and Q. Wu, 2016. Distribution and linkage disequilibrium analysis of polymorphisms of GH-1 gene in different populations of pigs associated with body size. $J$. Genet., 95: 79-87.

Chi, J.R., C.W. Huang, S.Y. Hu and J.L. Wu, 2014. Prolactin I microsatellite as genetic markers for characterization of five Oreochromis tilapia species and two Oreochromis niloticus strains. J Aquac Res. Dev., 5: 251. doi:10.4172/2155-9546.1000251.

Chistiakov, D.A., B. Hellemans, C.S. Haley, A.S. Law, C.S. Tsigenopoulos, G. Kotoulas, D. Bertotto, A. Libertini and F.A. Volckaert, 2005. A microsatellite linkage map of the European sea bass Dicentrarchus labrax L. Genetics, 170: 1821-1826.

Dias, M.A.D., R.V.R. Neto, J.S. de Sousa Bueno Filho, S.K.K. Jaser, A. de Assis Lago, A. and W. S. Hilsdorf, 2019. Growth hormone gene polymorphism associated with grow-out performance of Oreochromis niloticus strains. Aquaculture, 503: 105-110.

Eknath, A.E., H.B. Bentsen, R.W. Ponzoni, M. Rye, N.H. Nguyen, J. Thodesen and B. Gjerde, 2007. Genetic improvement of farmed tilapias: Composition and genetic parameters of a synthetic base population of Oreochromis niloticus for selective breeding. Aquaculture, 273(1):1-14.

Eynard, S.E., J.J. Windig, S.J. Hiemstra and M.P.L. Calus, 2016. Whole-genome sequence data uncover loss of genetic diversity due to selection. Genet. Sel. Evol., 48: 33. doi: 10.1186/s12711-016-0210-4.

FAO, 2018a. The State of World Fisheries and Aquaculture 2018 - Meeting the sustainable development goals. Rome. 210 p.

FAO. 2018b. FAO Fisheries Department, Fishery Information, Data and Statistics Unit. FishStatJ, a tool for fishery statistics analysis, Release: 3.04.5, Universal Software for Fishery Statistical Time Series. Global aquaculture production: Quantity 1950-2016; Value 1950-2016.

Gjedrem, T., N. Robinson and M. Rye, 2012. The importance of selective breeding in aquaculture to meet future demands for animal protein: A review. Aquaculture, 350-353: 117-129.

Haldar, C., 2018. Importance of marker assisted selection in fish breeding in India: Challenges and opportunities. Ann Aquac Res 5(1): 1047.

Hua, G., S. Chen, J. Yu, K. Cai, C. Wu and Q. Li, 2009. Polymorphism of the growth hormone gene and its association with growth traits in Boer goat bucks. Meat Sci., 81: 391-395.

Hussain, G., A.H.M. Kohinoor, M. Rahman, Z. Rahman and N.H. Nguyen, 2017. Bangladesh's tilapia aquaculture industry shows resilience. Glob. Aquac. Advoc., Monday, 17 July 2017.

Jaser, S.K.K., M.A.D. Dias, A.D.A. Lago, R.V.R. Neto and A.W.S. Hilsdorf, 2017. Single nucleotide polymorphisms in the growth hormone gene of Oreochromis niloticus and their association with growth performance. Aquac. Res., 48: 5835- 5845. 


\section{M.S. ZAFRIN AND M.S. ALAM}

Jauncy, K. and B. R. Ross, 1982. A guide to tilapia feeds and feeding. Institute of aquaculture, University of Sterling, Scotland. 111p.

Juhua, Y., C. Xuefeng, L. Jianlin, T. Yongkai, L. Hongxia, X. Pao and D. Zaijie, 2010. Isolation of IGF2 and association of IGF2 polymorphism with growth trait in genetically improved farmed tilapia, Oreochromis niloticus L. Aquac. Res., 41 (11): 41: e743-e750.

Kashi, Y. and D.G. King, 2006. Simple sequence repeats as advantageous mutators in evolution. Trends Genet., 22: 253-259.

Kawauchi, H. and S.A. Sower, 2006. The dawn and evolution of hormones in the adenohypophysis. Gen. Comp. Endocrinol., 148: 3-14.

Khatab, S. A., S.A. Hemeda, A.F. El-Nahas and W.S.A. El Naby, 2014. Genetic polymorphism in IGF-II gene and its relationship with growth rate in tilapia nilotica. Alexandria J. Vet. Sci., 43(1):26-32.

Liu, Z.J. and F.J. Cordes, 2004. DNA marker technologies and their applications in aquaculture genetics. Aquaculture, 238: 1-37.

Liu, X., H. Liang, Y. Liang, Z. Li, X. Qin and T. Zhang, 2017. Significant associations of polymorphisms in the growth hormone gene with growth traits in common carp (Cyprinus carpio). Meta Gene, 14: 38-41.

Peakall, R. and P.E. Smouse, 2012. GenAlEx 6.5: genetic analysis in Excel. Stock genetic software for teaching and research-an update. Bioinformatics 28: 2537-2539.

Peng,, F.L. and C. Luo, 2007. Cloning and tissue expression of insulin-like growth factor 2 gene in Carassius auratus. J. Nat. Sci. Hunan Norm. Univ., 30: 103-107.

Prabhu, E., C.B.T. Rajagopalsamy, B. Ahilan, I. Jegan, Michael Andro Jeevagan and M. Renuhadevi, 2019. Tilapia - An excellent candidate species for world aquaculture: a review. Ann. Res. Rev. Biol., 1(3): 1-14.

Reinecke, M., B.T. Björnsson, W.W. Dickhoff, S.D. McCormick, I. Navarro and D.M. Power, 2005. Growth hormone and insulin-like growth factors in fish: where we are and where to go. Gen. Comp. Endocrinol., 142: 20-24.

Romana-Eguia, M.R.R., M. Ikeda, Z.U. Basiao and N. Taniguchi, 2004. Genetic diversity in farmed Asian Nile and red hybrid tilapia stocks evaluated from microsatellite and mitochondrial DNA analysis. Aquaculture, 236: 131-150.

Sultana, N., M.G.Q. Khan, M.A.R. Hossain and M.S. Alam, 2020. Allelic segregation of sex-linked microsatellite markers in Nile tilapia (Oreochromis niloticus) and validation of inheritance in YY population. Aquac. Res., 51:1923-1932.

Tsai, H.J., J.C. Kuo, S.W. Lou and T.T. Kuo, 1994. Growth enhancement of juvenile striped mullet by feeding recombinant yeasts containing fish growth hormone. Prog. Fish-Cult. 56: 7-12.

Wang, X., S. Jiang, L. Zheng, L. Xiao, X. Zhang, D. Wang and X. You, 2019. An SNP-Based Genetic Map and QTL Mapping for Growth Traits in the Red-Spotted Grouper (Epinephelus akaara). Genes 10(10): 793. doi: 10.3390/genes10100793.

Yue, G.H. and L. Orban, 2002. Microsatellites from genes show polymorphism in two related Oreochromis species. Molec. Ecol. Notes 2(2): 99-100.

Zhang, Z. F., H. Chen, Q.L. Li, C.Z. Lei and K. Xue, 2007: Study on the polymorphism in exon2 of insulin-like growth factor2 gene and its relationship with several growth traits in Nanyang Cattle. Acta Vet. Et Zootech. Sinica, 38: 8-13. 